\title{
Assessment of Undiscovered Oil and Gas Resources of the Southern Siberian Craton (Baykit High, Nepa-Botuoba High, Angara-Lena Terrace, and Cis-Patom Foredeep Provinces), Russia, 2011
}

Using a geology-based assessment methodology, the U.S. Geological Survey estimated volumes of undiscovered, technically recoverable, conventional petroleum resources for the southern Siberian craton provinces of Russia. The mean volumes were estimated at 3.0 billion barrels of crude oil, 63.3 trillion cubic feet of natural gas, and 1.2 billion barrels of natural gas liquids.

\section{Introduction}

The U.S. Geological Survey (USGS) estimated volumes of undiscovered, technically recoverable, conventional oil and gas resources of the Baykit High, Nepa-Botuoba High, AngaraLena Terrace, and Cis-Patom Foredeep Provinces in Russia. The assessment is part of a program to estimate petroleum resources for priority basins around the world, specifically for total petroleum systems (TPS) and assessment units (AU) that are defined on the basis of their geologic attributes that are favorable for the generation and accumulation of petroleum. The Baykit High Province, encompassing about 202,661 square kilometers $\left(\mathrm{km}^{2}\right)$ (fig. 1), contains a TPS that had undergone a tectonic, and, presumably, a petroleum-generation history that was different

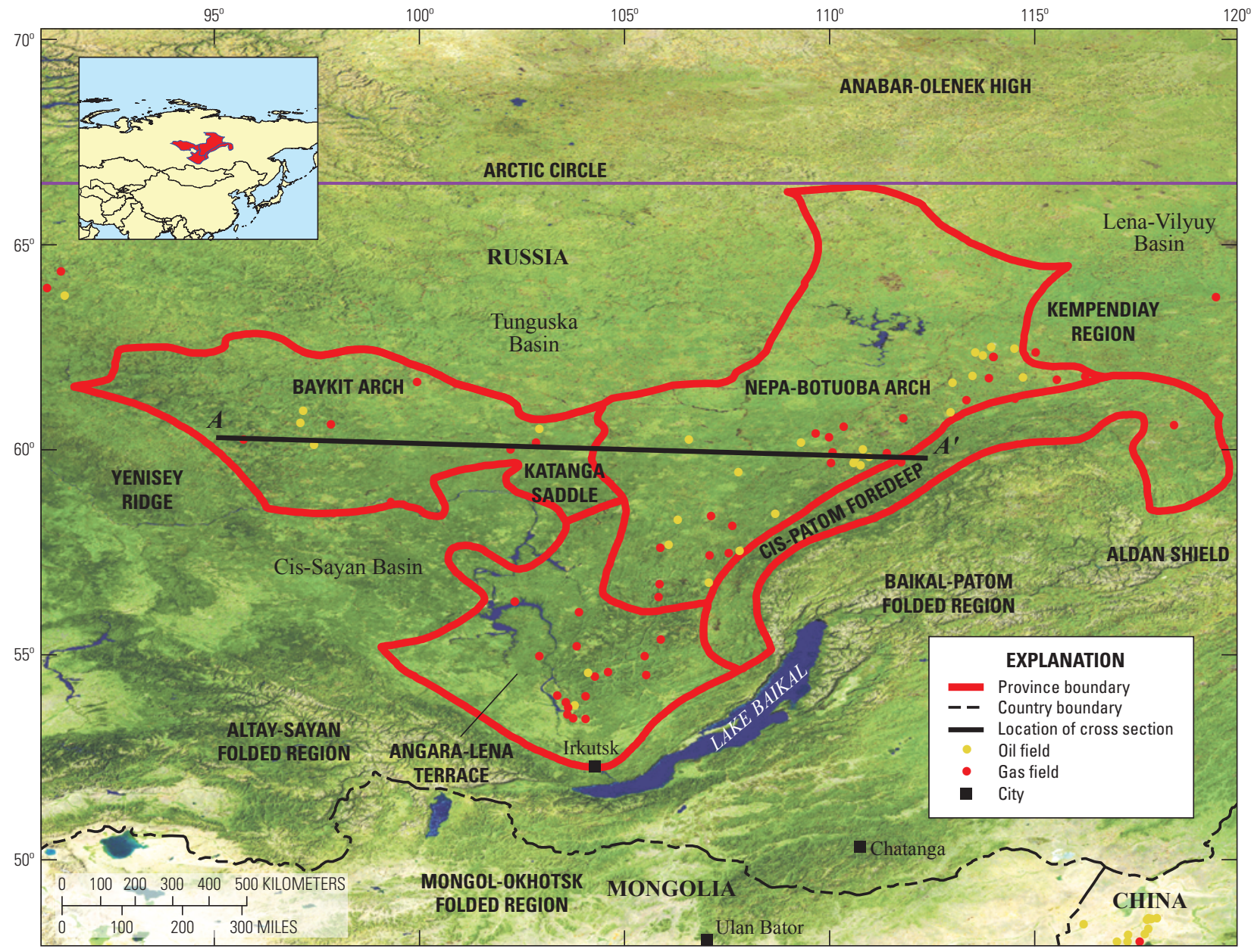

Figure 1. Generalized map showing the boundaries of the Baykit High, Nepa-Botuoba High, Angara-Lena Terrace, and Cis-Patom Foredeep Provinces, Russia; major geologic features; centerpoints of oil and gas fields; and the location of geologic cross section $A-A^{\prime}$ shown in figure 2. Field data from IHS Energy (2009); geologic province boundaries from Persits and others (1998) and Ulmishek (2001a, b). 
from the other geologic provinces and therefore the province was assessed separately. The Nepa-Botuoba High, Angara-Lena Terrace, and Cis-Patom Foredeep Provinces, however, were assessed collectively as one TPS and AU because of a paucity of data, and that the same TPS most likely spans all of the provinces. These three geologic provinces encompass a total area of $669,137 \mathrm{~km}^{2}$ (fig. 1). This assessment was based on published geologic information and on commercial data from oil and gas wells and fields, and from field production records.

\section{Total Petroleum Systems and Assessment Units}

The Baykit High Province and the combined area of the Nepa-Botuoba High, Angara-Lena Terrace, and Cis-Patom Foredeep Provinces are interpreted to have originated as rifted passive margin basins, which controlled the distribution of upper Proterozoic source rocks, as well as the oil and gas resources. The rifted-passive margin basins underwent compression and deformation during the late Proterozoic (Baikalian orogeny) by collision of continental blocks with the Siberian craton and again during the late Paleozoic (Hercynian orogeny) by collision of the Kazakh, Siberian, and Eurasian continents (Ulmishek, 2001a, b).

Two TPSs were defined and called Proterozoic-Paleozoic Composite TPSs (table 1), one for the Baykit High Province and another for the Nepa-Botuoba High, Angara-Lena Terrace, and Cis-Patom Foredeep Provinces. They both include upper Proterozoic petroleum source rocks and upper Proterozoic through Cambrian reservoir rocks. One AU containing conventional undiscovered oil and gas resources was defined geologically and called Proterozoic-Paleozoic AUs, one for the Baykit High Province and another for the Nepa-Botuoba High, Angara-Lena Terrace, and Cis-Patom Foredeep Provinces (figs. 1 and 2).

Major source rocks are upper Proterozoic marine shales (Ulmishek, 2001a, b). Source rocks for the Baykit High Province were located in areas to the present-day west and southwest of the province and in depressions within the province. Source rocks outside the present-day province boundary were subjected

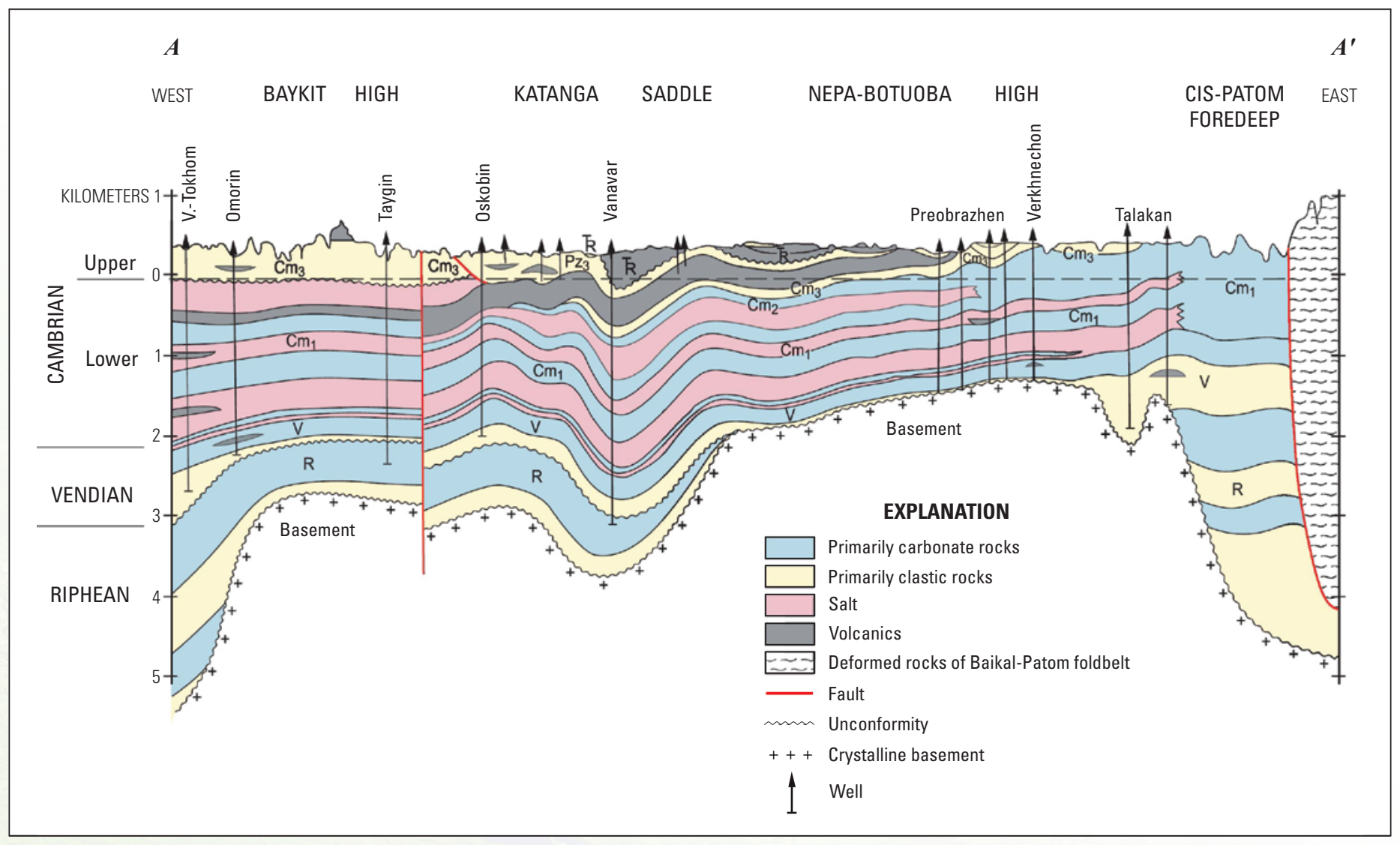

Figure 2. Geologic cross section across the Baykit High, Nepa-Botuoba High, Angara-Lena Terrace, and Cis-Patom Foredeep Provinces, Russia. See figure 1 for location. From Ulmishek (2001a, modified from Gabrielyants, 1991). $\mathrm{Cm}_{1}, \mathrm{Cm}_{2^{\prime}} \mathrm{Cm}_{3^{\prime}}$ Lower, Middle, and Upper Cambrian, respectively; $\mathrm{R}$, Riphean; $\mathrm{V}$, Vendian; $\mathrm{Pz}_{3^{\prime}}$ upper Paleozoic; $\mathrm{T}_{\mathrm{R}^{\prime}}$ Lower Triassic. Approximate length of cross section 1,000 kilometers. 
to deformation and metamorphism during the Late Proterozoic Baikalian orogeny (850-820 Ma). The Proterozoic source rocks outside the province matured during the late Proterozoic, but the accumulations were destroyed by Baikalian deformation. Source rocks within the province attained maximum maturity during the early Paleozoic, after Early Cambrian evaporite deposition. Source rocks for the Nepa-Botuoba High, AngaraLena Terrace, and Cis-Patom Foredeep Provinces are hypothesized to have been located in areas to the present-day south and southeast of the provinces, in the Baikal-Patom Folded Region (fig. 1) (Ulmishek, 2001a). Age of maturation of these Proterozoic source rocks is unknown, but most likely occurred before Silurian or Devonian deformation. In all of the provinces, most known recoverable crude oil and natural gas accumulations have been discovered in upper Proterozoic carbonate and clastic rocks and Cambrian carbonate rocks (Ulmishek, 2001a, b). Lower Cambrian evaporates provide a regional seal, whereas other seal rocks include intraformational shales. Identified traps include combination structural and stratigraphic, such as pinchouts on crests of uplifts with updip seals, faulted anticlines, local uplifts, and reef- and carbonate-platform-associated facies.

Although a few large fields have been discovered Yurubchen-Tokhom (oil), Soba (gas), and Kovyktinskoye (gas) - much of the Baykit High, Nepa-Botuoba High, Angara-Lena Terrace, and Cis-Patom Foredeep Provinces is unexplored. Future potential for discoveries exists in smaller structural and stratigraphic traps. Poor reservoir quality and the absence of source rocks pose challenges for the discovery of additional accumulations.

\section{Assessment Results}

Estimates of volumes of undiscovered technically recoverable, conventional oil and gas resources are shown in table 1. No attempt was made to estimate economically recoverable resources because it is beyond the scope of this study. In summary, the estimated mean volumes of undiscovered, technically recoverable, conventional oil and gas resources for the Baykit High Province are approximately 426 million barrels (MMB) of crude oil, 2,071 billion cubic feet (BCF) of natural gas (721 BCF of associated and dissolved natural gas and 1,350 BCF of nonassociated natural gas), and $38 \mathrm{MMB}$ of natural gas liquids (9 MMB of natural gas liquids in oil accumulations and $29 \mathrm{MMB}$ of total liquids in nonassociated gas accumulations).

The estimated mean volumes of undiscovered, technically recoverable, conventional oil and gas resources for the NepaBotuoba High, Angara-Lena Terrace, and Cis-Patom Foredeep Provinces are approximately 2,599 MMB of crude oil, 61,259 $\mathrm{BCF}$ of natural gas $(12,845 \mathrm{BCF}$ of associated and dissolved natural gas and 48,414 BCF of nonassociated natural gas), and 1,148 MMB of natural gas liquids (60 MMB of natural gas liquids in oil accumulations and 1,088 MMB of total liquids in nonassociated gas accumulations).

The total estimated mean volumes of undiscovered, technically recoverable, conventional oil and gas resources for all of the South Siberian Basin Provinces are approximately 3,025 MMB of crude oil, $63,330 \mathrm{BCF}$ of natural gas $(13,566 \mathrm{BCF}$ of associated and dissolved natural gas and 49,764 BCF of nonassociated natural gas), and 1,186 MMB of natural gas liquids (69 MMB of natural gas liquids in oil accumulations and 1,117 MMB of total liquids in nonassociated gas accumulations).

Table 1. Southern Siberian craton assessment results (undiscovered, technically recoverable, conventional resources).

[MMB, million barrels; BCF, billion cubic feet. Results shown are fully risked estimates. For gas fields, all liquids are included under the natural gas liquids (NGL) category. F95 denotes a 95-percent chance of at least the amount tabulated. Other fractiles are defined similarly. Fractiles are additive under the assumption of perfect positive correlation. TPS, total petroleum system; AU, assessment unit. Gray shading indicates not applicable]

\begin{tabular}{|c|c|c|c|c|c|c|c|c|c|c|c|c|c|c|}
\hline \multirow{3}{*}{$\begin{array}{l}\text { Total petroleum systems } \\
\text { (TPS) } \\
\text { and assessment units (AU) }\end{array}$} & \multirow{3}{*}{$\begin{array}{l}\text { Field } \\
\text { type }\end{array}$} & \multirow{3}{*}{$\begin{array}{l}\text { Mean (expected) } \\
\text { largest } \\
\text { field size } \\
\text { (MMB or BCF) }\end{array}$} & \multicolumn{12}{|c|}{ Total undiscovered resources } \\
\hline & & & \multicolumn{4}{|c|}{ Oil (MMB) } & \multicolumn{4}{|c|}{ Gas (BCF) } & \multicolumn{4}{|c|}{ NGL (MMB) } \\
\hline & & & $\mathrm{F95}$ & $\mathrm{F} 50$ & $\overline{F 5}$ & Mean & F95 & F50 & $\mathrm{F} 5$ & Mean & F95 & F50 & $\mathrm{F5}$ & Mean \\
\hline \multicolumn{15}{|c|}{ Baykit High Province, Proterozoic-Paleozoic Composite TPS } \\
\hline \multirow{2}{*}{ Proterozoic-Paleozoic AU } & Oil & 127 & 116 & 365 & 943 & 426 & 184 & 601 & 1,678 & 721 & 2 & 7 & 21 & 9 \\
\hline & Gas & 151 & & & & & 538 & 1,221 & 2,616 & 1,350 & 12 & 27 & 57 & 29 \\
\hline \multicolumn{15}{|c|}{ Nepa-Botuoba High, Angara-Lena Terrace, and Cis-Patom Foredeep Provinces, Proterozoic-Paleozoic Composite TPS } \\
\hline \multirow{2}{*}{ Proterozoic-Paleozoic AU } & Oil & 531 & 1,004 & 2,388 & 4,944 & 2,599 & 4,785 & 11,627 & 25,112 & 12,845 & 22 & 54 & 121 & 60 \\
\hline & Gas & 11,213 & & & & & 17,154 & 44,205 & 94,321 & 48,414 & 361 & 961 & 2,264 & 1,088 \\
\hline $\begin{array}{l}\text { Total undiscovered petroleum } \\
\text { resources }\end{array}$ & & & & & & 3,025 & & & & 63,330 & & & & 1,186 \\
\hline
\end{tabular}




\section{References Cited}

Gabrielyants, G.A., ed., 1991, Regional geology of petroleum provinces of the USSR (Regionalnaya Geologiya neftegazonosnykh territoriy SSSR): Moscow, Nedra, 284 p.

IHS Energy, 2009 [includes data current through October 2009], International exploration and production database: Englewood, Colo., IHS Energy.

Persits, F.M., Ulmishek, G.F., and Steinshouer, D.W., 1998, Map showing geology, oil and gas fields, and geologic provinces of the former Soviet Union: U.S. Geological Survey Open-File Report 97-470E, CD-ROM.

Ulmishek, G.F., 2001a, Petroleum geology and resources of the Nepa-Botuoba High, Angara-Lena Terrace, and Cis-Patom Foredeep, southeastern Siberian craton, Russia: U.S. Geological Survey Bulletin 2201-C, 16 p.

Ulmishek, G.F., 2001b, Petroleum geology and resources of the Baykit High Province, East Siberia, Russia: U.S. Geological Survey Bulletin 2201-F, 18 p.

\section{For Further Information}

Supporting geologic studies of total petroleum systems and assessment units, reports on the methodology used in the assessment of the Baykit High Province and Nepa-Botuoba High, Angara-Lena Terrace, and Cis-Patom Foredeep Provinces, and assessment results are available at the USGS Central Energy Resources Science Center website: http://energy.usgs.gov.

\section{South Siberian Basin Provinces Assessment Team}

T.R. Klett (tklett@usgs.gov), Christopher J. Schenk, Craig J. Wandrey, Ronald R. Charpentier, Michael E. Brownfield, Janet K. Pitman, Richard M. Pollastro, Troy A. Cook, and Marilyn E. Tennyson. 